CARADDE: Jurnal Pengabdian Kepada Masyarakat
$\begin{gathered}\text { https://journal.ilininstitute.com/index.php/caradde } \\ \text { Volume 2 I Nomor 1 I Agustus I2019 } \\ \text { e-ISSN: 2621-7910 dan p-ISSN: 2621-7961 }\end{gathered}$

\title{
Pemberdayaan Masyarakat Desa Lero Dalam Bidang Kesehatan Melalui Penyuluhan Penggunaan Antibiotik
}

Eka Astuty ${ }^{1}$, Nuraeni Syarifuddin ${ }^{2}$

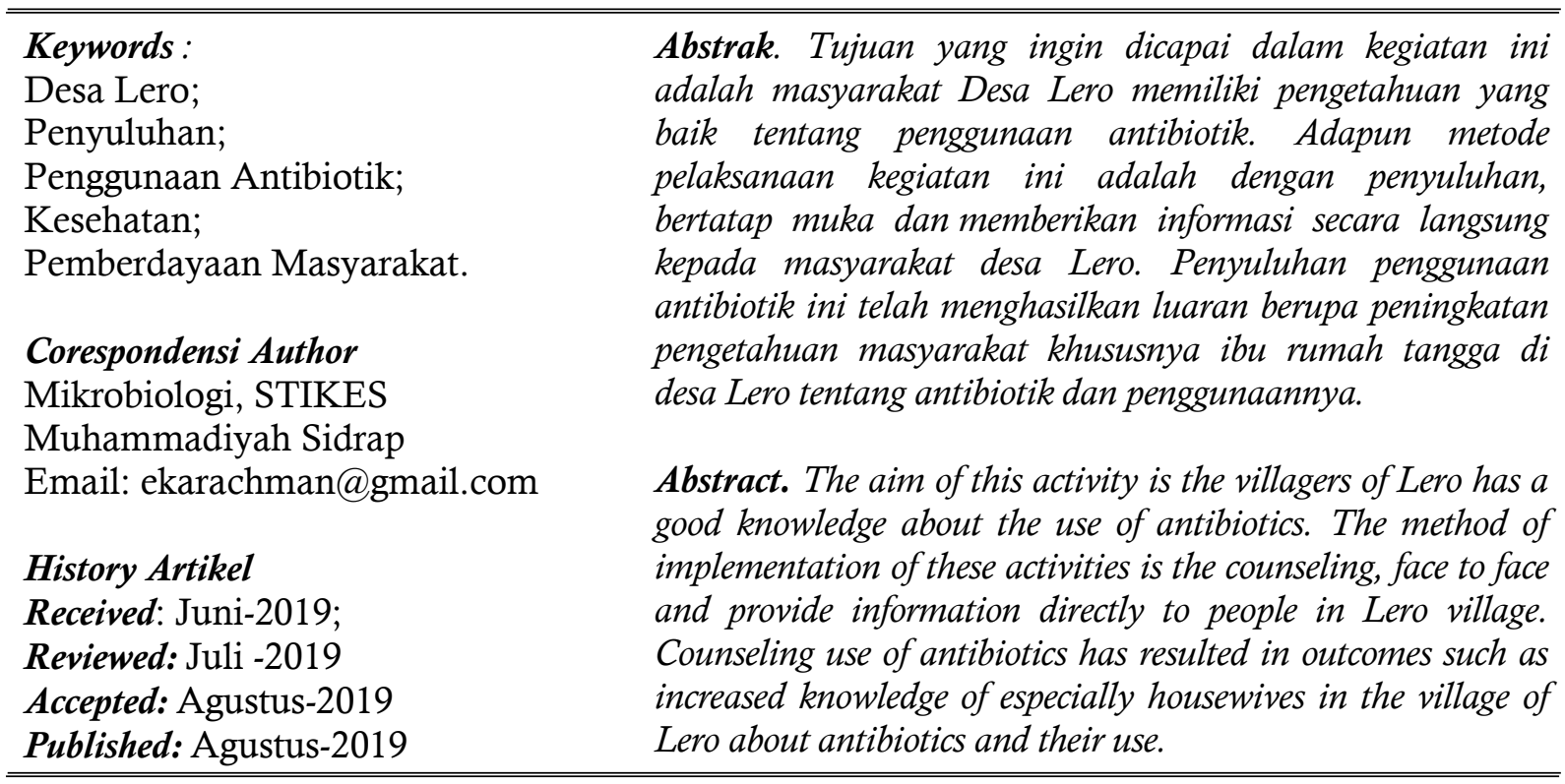

This work is licensed under a Creative Commons Attribution

4.0 International License

\section{PENDAHULUAN}

Darurat antibiotik sudah berlangsung hampir satu dekade belakangan ini. Puncaknya pada tanggal 7 April 2011 lalu bertepatan dengan peringatan hari Kesehatan Dunia dimana WHO secara resmi memperkenalkan program Combating Antibiotic Resistance kepada seluruh negara dan organisasi kesehatan di dunia (Asharina, 2016). Dalam penelitiannya (Yarza, Yanwirasti, \& Irawati, 2015) menyatakan bahwa peresepan antibiotik di Indonesia yang cukup tinggi dan kurang bijak meningkatkan kejadian resistensi. Khusus untuk kawasan Asia Tenggara, penggunaan antibiotik sangat tinggi bahkan lebih dari $80 \%$ di banyak provinsi di Indonesia. Menurut penelitian (Utami, 2010),
$92 \%$ masyarakat Indonesia tidak menggunakan antibiotik secara tepat. Penggunaan antibiotik akan menguntungkan dan memberikan efek bila diresepkan dan dikonsumsi sesuai dengan aturan. Namun, sekarang ini antibiotik telah digunakan secara bebas dan luas oleh masyarakat tanpa mengetahui dampak dari pemakaian tanpa aturan. Kurangnya pemahaman masyarakat dan informasi dari tenaga kesehatan, menyebabkan masyarakat menggunakan antibiotik tanpa supervisi tenaga kesehatan. Persepsi yang salah pada masyarakat dan banyaknya masyarakat yang membeli antibiotik secara bebas tanpa resep dokter memicu terjadinya masalah resistensi antibiotik. (Baroroh, Utami, Maharani, \& Mustikaningtias, 2018) dalam penelitiannya di Desa Sambeng Wetan, kecamatan 
Caradde: Jurnal Pengabdian Kepada Masyarakat Vol 2 No 1, Agustus 2019

Kembaran Kabupaten Banyumas, mengungkapkan bahwa penggunaan antibiotik yang tidak tepat terjadi karena minimnya informasi dari tenaga kesehatan. Jumlah petugas kesehatan di desa tersebut tidak sebanding dengan jumlah penduduk yang sangat membutuhkan perhatian terutama bidang kesehatan khususnya informasi terkait penggunaan obat yang rasional. Selain itu penjualan antibiotik secara bebas masih terjadi di apotek, bahkan di warung pun ada penjualan antibiotik.

Hingga saat ini, bentuk tanggung jawab pemerintah Indonesia terhadap upaya mengendalikan resistensi antibiotik telah dilakukan dalam bentuk Permenkes RI Nomor 2046/MENKES/PER/2011 tentang Pedoman Umum Penggunaan Antibotik. Permenkes dibuat untuk mengoptimalkan penggunaan antibiotik secara bijak (prudent use of antibiotics). Kementerian Kesehatan juga telah membentuk KPRA (Komisi Pengendalian Resistensi Antibiotik), yang terdiri dari pengambil kebijakan bidang kesehatan, organisasi profesi, dan lembaga swadaya masyarakat, untuk dapat bekerja sama menjadi penjuru dalam mengembangkan dan mengawal program pengendalian resistensi antimikroba secara luas, baik di fasilitas pelayanan kesehatan maupun di masyarakat.

Suatu tinjauan mengenai penggunaan antibiotika di negara berkembang yang ditulis oleh Radyowijati dan Haak melaporkan bahwa masyarakat mempercayai antibiotika sebagai "obat yang luar biasa" atau "obat dewa" yang dapat mencegah maupun mengobati berbagai penyakit ataupun gejala. Konsep pemikiran yang salah dan kurangnya pengetahuan dasar tentang penggunaan antibiotika juga dilaporkan pada beberapa studi baik pada negara berkembang dan yang sedang berkembang (Aris, Sri, Charlotte, \& E, 2012)

Desa Lero adalah salah satu Desa yang ada di Kecamatan Suppa Kabupaten Pinrang yang luasnya $\pm 47 \mathrm{Ha}$, berjarak 17 $\mathrm{Km}$ dari ibukota kecamatan, $37 \mathrm{Km}$ dari Ibukota Kabupaten dan $215 \mathrm{Km}$ dari ibukota provinsi. Sebagian besar masyarakat Desa Lero bekerja sebagai nelayan dan jenjang pendidikan masyarakat Desa Lero yang paling menonjol adalah hanya sebatas menamatkan sekolah dasar bahkan beberapa

masyarakatnya tidak menamatkan sekolah dasar (Rakib \& Syam, 2016). Hal ini menunjukkan bahwa tingkat pendidikan di desa Lero masih tergolong rendah.

Berikut permasalahan mitra yang diperoleh melalui observasi dan survei di lapangan (Tabel 1), berdasarkan data dan fakta yang ada perlu dilakukan upaya kesehatan berbasis masyarakat melalui pemberdayaan masyarakat, salah satunya melalui penyuluhan penggunaan antibiotik. (Lubis, Meilani, Yuniarti, \& Dalimunthe, 2019) dalam kegiatan pengabdian masyarakat di Lingkungan III, Kelurahan Tembung, Kecamatan Medan Tembung, Kota Medan menyatakan bahwa kegiatan edukasi dengan metode presentasi, ceramah dan diskusi tentang pengetahuan pengenalan dan tujuan penggunaan antibiotik, penggunaan antibiotik yang tepat dan resistensi antibiotik dapat meningkatkan pengetahuan masyarakat

Masyarakat perlu memahami bahwa dalam pelayanan kesehatan, antibiotik harus digunakan secara tepat dan rasional, agar mencapai efek pengobatan.

Tabel 1. Permasalahan mitra Desa Lero

\begin{tabular}{|c|c|c|}
\hline No & Permasalahan & Uraian \\
\hline 1. & \begin{tabular}{l}
\multicolumn{3}{l}{ Masyarakat } \\
Desa Lero \\
memiliki akses \\
terhadap \\
fasilitas \\
kesehatan
\end{tabular} & $\begin{array}{l}\text { Masyarakat di Desa } \\
\text { Lero memiliki akses } \\
\text { terhadap fasilitas } \\
\text { kesehatan, termasuk } \\
\text { didalamnya } \\
\text { penggunaan } \\
\text { antibiotik, baik yang } \\
\text { diresepkan oleh } \\
\text { dokter, obat bebas } \\
\text { maupun obat bebas } \\
\text { terbatas yang dapat } \\
\text { dibeli sesuai dengan } \\
\text { gejala penyakit yang } \\
\text { dirasakan }\end{array}$ \\
\hline 2. & \begin{tabular}{lr}
\multicolumn{2}{l}{ Masyarakat } \\
Desa Lero \\
sebagian besar \\
memiliki JKN \\
(Jaminan & \\
Kesehatan & \\
Nasional) &
\end{tabular} & $\begin{array}{l}\text { Era jaminan } \\
\text { kesehatan nasional } \\
\text { berimbas pada } \\
\text { peningkatan } \\
\text { motivasi masyarakat } \\
\text { setempat untuk } \\
\text { memeriksa kesehatan } \\
\text { secara rutin di pusat } \\
\text { pelayanan kesehatan }\end{array}$ \\
\hline
\end{tabular}


Astuty, Syarifuddin. Pemberdayaan Masyarakat Desa

setempat menjadi
sebab peredaran
antibiotik yang
cukup banyak di
masyarakat. Namun
penggunaan
antibiotik yang
semakin banyak ini
belum didukung
secara optimal
dengan pengetahuan
masyarakat
mengenai cara
konsumsi hingga
pembuangan limbah
antibiotik.

\section{METODE}

Metode yang digunakan dalam pelaksanaan kegiatan adalah penyuluhan (Gambar 2), dengan bertatap muka dan memberikan informasi secara langsung kepada masyarakat desa lero, yang diharapkan dapat lebih efektif dibandingkan dengan tindakan penyuluhan melalui media massa ataupun selebaran.

\section{HASIL DAN PEMBAHASAN}

Kegiatan penyuluhan penggunaan antibiotik merupakan salah satu rangkaian kegiatan pengabdian masyarakat dosen STIKES Muhammadiyah Sidrap Tahun 2019, tepatnya pada tanggal 27 maret 2019, yang dipusatkan di Desa Lero, Kec. Suppa, Kab. Pinrang, Sulawesi Selatan. Sasaran kegiatan penyuluhan ini adalah ibu-ibu rumah tangga yang ada di desa Lero. Hal tersebut mengingat ibu-ibu rumah tangga di desa Lero pada umumnya memiliki banyak waktu luang. Selain itu, melibatkan ibu-ibu sebagai subjek utama dikarenakan ibu merupakan pilar kesehatan dalam keluarga. Ibu memegang peran penting dalam mengatur dan mengurus banyak hal dalam rumah tangga, termasuk penyediaan obat keluarga (Kemendikbud, 2017).

Kegiatan ini dimulai dengan menyediakan tempat pelaksanaan kegiatan penyuluhan. Sebelum penyuluhan dimulai, kami terlebih dahulu melakukan pre-test sederhana, berupa pertanyaan-pertanyaan tentang antibiotik kepada ibu-ibu rumah tangga yang hadir (responden). Kuesioner dibagikan kepada responden sebelum dan sesudah memperoleh penyuluhan. Kuesioner berisi 10 pertanyaan terkait pengetahuan mengenai penggunaan antibiotik. Data skor pre-test dan post-test yang diperoleh kemudian diolah dan dianalisis. Jumlah keseluruhan peserta penyuluhan adalah 35 orang namun hanya 31 orang yang bersedia mengisi kuesioner. Total kuesioner yang dianalisis adalah 31 kuesioner pre-test dan posttest. Data menunjukkan bahwa sebagian besar responden merupakan usia lansia awal (middle age) yaitu $46-55$ tahun $(83,7 \%)$. Pendidikan responden sebagian besar adalah tamat SMP $(38,5 \%)$ dan bekerja sebagai ibu rumah tangga $(90,3 \%)$

Berdasarkan hasil analisis data, menunjukkan bahwa sebelum dilakukan penyuluhan, responden yang memiliki pengetahuan yang baik berjumlah 5 orang $(16,12 \%)$, pengetahuan cukup berjumlah 7 orang $(22,58 \%)$ dan yang memiliki tingkat pengetahuan kurang tentang penggunaan antibiotik sebanyak 19 orang $(61,29 \%)$. Hasil ini menunjukkan bahwa sebagian besar dari resonden tidak memahami istilah antibiotik dan bagaimana penggunaanya, yang mereka pahami, bahwa ketika mereka terkena demam dan diare, mereka akan ke warung terdekat, bukan toko obat apalagi apotik, untuk membeli ampicilin (salah satu merk antibiotik) tanpa resep dokter dan aturan pemakaian.

Dalam kegiatan pengabdian masyarakat ini, penyuluhan kami lakukan dengan menggunakan bantuan LCD/Proyektor, disetiap slide kami tampilkan materi presentasi yang menarik (dilengkapi dengan video) tentang definisi umum antibiotik, jenis-jenis antibiotik, dan penggunaan antibiotik yang baik dan benar. Ibu-ibu rumah tangga yang hadir tampak antusias menyimak materi yang sampaikan.

Kegiatan penyuluhan diakhiri dengan sesi tanya jawab dimana respon masyarakat khususnya para ibu rumah tangga yang hadir, cukup baik, terlihat dari banyaknya pertanyaan yang disampaikan kepada pemateri. Diantaranya adalah pertanyaan tentang aturan pakai antibiotik, yang selama ini mereka pahami, bahwa antibiotik tak perlu dihabiskan. Kemudian pertanyaan tentang bagaiman cara menyimpan obat dan cara membuang obat yang benar.

Berbagai pertanyaan tersebut merupakan wujud keingintahuan 
Caradde: Jurnal Pengabdian Kepada Masyarakat

Vol 2 No 1, Agustus 2019

masyarakat mengenai penggunaan obat antibiotik yang baik dan benar sehingga diharapkan melalui kegiatan penyuluhan ini, tujuan akhir yang ingin dicapai dapat tercapai dan masyarakat menjadi lebih perhatian dalam mengonsumsi dan mengelola obat yang ada di lingkungan keluarganya masingmasing khususnya.

Pengetahuan dan kepercayaan merupakan faktor sosial kognitif yang mempengaruhi perilaku terkait kesehatan pada level individu, termasuk perilaku penggunaan antibiotik. Pengetahuan sendiri sangat dipengaruhi oleh pendidikan. Semakin tinggi tingkat pendidikan yang dimiliki maka semakin mudah orang tersebut menerima informasi, sehingga, pengetahuannya akan semakin baik. Berdasarkan hasil penelitian (Ivoryanto, Sidharta, \& Illahi, 2017) terdapat hubungan positif dan tinggi antara tingkat pendidikan formal masyarakat dengan tingkat pengetahuan dalam penggunaan antibiotika. Berdasarkan hasil penelitian ini juga didapatkan bahwa pendidikan formal memiliki pengaruh tinggi terhadap tingkat pengetahuan dalam penggunaan antibiotika pada gender perempuan dan responden yang berusia 18-28 tahun. Tingkat pendidikan masyarakat desa lero yang rendah bisa menjadi salah satu penyebab mengapa tingkat kesehatan masyarakat Desa Lero masih jauh dari standar, termasuk didalamnya tingkat pengetahuan tentang penggunaan antibiotik.

(Oh et al., 2011) mengemukakan bahwa pengetahuan dan sikap terhadap antibiotika di masyarakat memainkan peran penting dalam keberhasilan proses pengobatan. Terjadi peningkatan pengetahuan penggunaan antibiotika yang lebih baik sesudah penyuluhan dari pada sebelum penyuluhan, dimana ini memperkuat kesimpulan (Aris et al., 2012) yang menyatakan bahwa perlunya peningkatan pengetahuan mengenai penggunaan antibiotika yang tepat dan perlunya intervensi untuk mengurangi kesalahpahaman mengenai penggunaan antibiotika dan meningkatkan kesadaran masyarakat mengenai resiko penggunaan antibiotika yang tidak tepat di masyarakat. Intervensi dalam penelitian yang diberikan ialah penyuluhan secara langsung kepada masyarakat.

Penyuluhan kesehatan merupakan suatu bentuk kegiatan edukasi yang dapat mempengaruhi pengetahuan dan sikap. Dengan adanya kegiatan edukasi berupa penyuluhan maka responden akan memperoleh pembelajaran dan informasi yang menghasilkan suatu perubahan perilaku termasuk pengetahuan dan sikap.

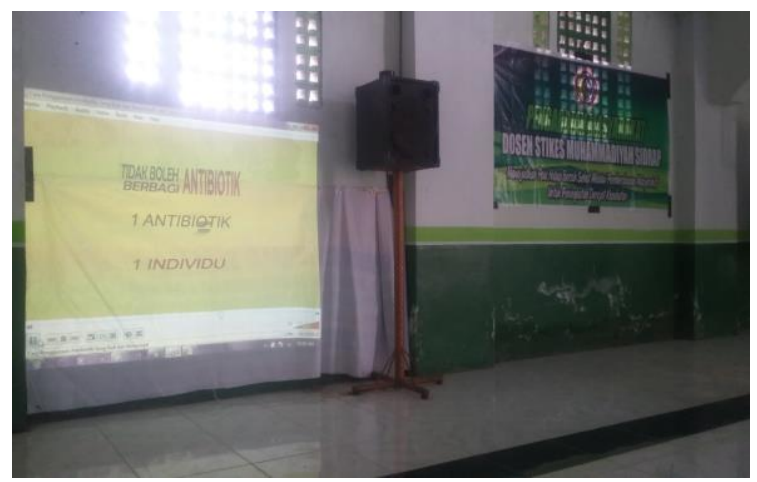

Gambar 1. Penyuluhan penggunaan antibiotik
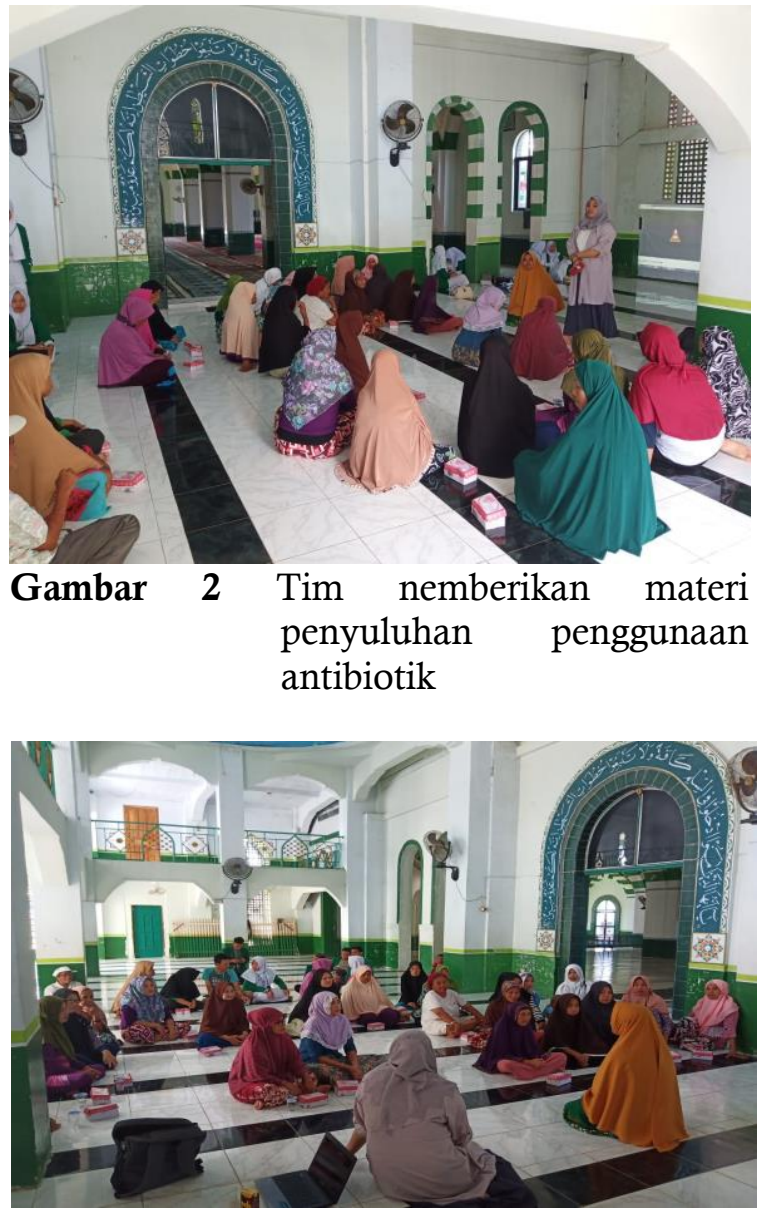

Gambar 3 Sesi tanya jawab dengan masyarakat terkait materi penyuluhan 


\section{SIMPULAN DAN SARAN}

Dengan demikian, dapat dikemukakan bahwa dengan adanya penyuluhan penggunaan antibiotik ini telah menghasilkan luaran berupa peningkatan pengetahuan masyarakat khususnya ibu rumah tangga di desa Lero tentang antibiotik dan penggunaannya.

Diharapkan kedepannya, petugas kesehatan lebih sering memantau peredaran antibiotik dan mengedukasi masyarakat desa Lero tentang bahaya resistensi yang disebabkan oleh kesalahan penggunaan antibiotik

\section{DAFTAR RUJUKAN}

Aris, W., Sri, S., Charlotte, de C., \& E, H. J. (2012). Knowlwdge and beliefs about antibiotics among people in Yogyakarta City Indonesia: a cross sectional population-based survey. Antimicrobial Resistance and Infection Control, 1(38), 491.

Asharina, I. (2016). Resistensi Antibiotik Di Indonesia-Tak Usah Dulu Bermain UndangUndang.

https://doi.org/10.13140/RG.2.2.21560 65281

Baroroh, H., Utami, E., Maharani, L., \& Mustikaningtias, I. (2018). Peningkatan Pengetahuan Masyarakat Melalui Edukasi Tentang Penggunaan Antibiotik Bijak dan Rasional. Ad-Dawaa Jour. Pharm. Sci, 1(1), 8-15. Retrieved from http://journal.uin-

alauddin.ac.id/index.php/addawaa/arti cle/view/6425

Ivoryanto, E., Sidharta, B., \& Illahi, R. K. (2017). Hubungan Tingkat Pendidikan Formal Masyarakat terhadap Pengetahuan dalam Penggunaan Antibiotika Oral di Apotek Kecamatan Klojen. Pharmaceutical Journal of Indonesia, 2(2), 31-36. https://doi.org/10.21776/ub.pji.2017.00 2.02.1

Lubis, M. S., Meilani, D., Yuniarti, R., \& Dalimunthe, G. I. (2019). Pkm Penyuluhan Penggunaan Antibiotik
Kepada Masyarakat Desa Tembung. Amaliah: Jurnal Pengabdian Kepada Masyarakat, 3(1), 297-301. https://doi.org/10.32696/ajpkm.v3i1.24 6

Oh, A. L., Hassali, M. A., Al-Haddad, M. S., Sulaiman, S. A. S., Shafie, A. A., \& Awaisu, A. (2011). Public knowledge and attitudes towards antibiotic usage: A cross-sectional study among the general public in the state of Penang, Malaysia. Journal of Infection in Developing Countries, 5(5), 338-347.

Rakib, M., \& Syam, A. (2016). Pemberdayaan Masyarakat Melalui Program Life Skills Berbasis Potensi Lokal Untuk Meningkatkan Produktivitas Keluarga Di Desa Lero Kecamatan Suppa Kabupaten Pinrang. Jurnal Ilmiah Ilmu Administrasi Publik, 6(1), 96. https://doi.org/10.26858/jiap.v6i1.2155

Utami, E. R. Antibiotika, Resistensi, dan Rasionalitas Terapi, 1El-Hayah 191-198 (2010).

Yarza, H. L., Yanwirasti, Y., \& Irawati, L. (2015). Hubungan Tingkat Pengetahuan dan Sikap dengan Penggunaan Antibiotik Tanpa Resep Dokter. Jurnal Kesehatan Andalas, 4(1), 151-156.

Peraturan Menteri Kesehatan Republik Indonesia Nomor 2406/Menkes/Per/XII/2011.

http://www.Binfar.Depkes.Go.Id/Dat/ Permenkes_ Antibiotik.Pdf , accessed March, 2019

Kemendikbud. Rakerkesnas 2017: Integrasi Seluruh Komponen Bangsa Mewujudkan Indonesia Sehat 